\title{
Possessives and grammaticalization in Romance
}

\begin{abstract}
This paper deals with possessives in French, Italian, Spanish and Romanian. As is well known, the possessive paradigms of these languages contain three types of possessives: adjectives, determiners and pronouns (see Cardinaletti 1998, Schoorlemmer 1998, Zribi-Hertz 1999, Ihsane 2000, Alexiadou 2004). When comparing these with the Latin system, from which all Romance possessive systems derive, two tendencies prevail: (i) possessive pronouns tend to be eliminated, and (ii) possessive adjectives change into determiners or become deficient adjectives with a restricted distribution.

A thorough study of each available type in the four languages, however, shows that the possessive system of each of these four languages is different. The aim of this paper is to examine the extent to which these differences are the result of different degrees of grammaticalization. Our investigation shows that the possessive system in French is in the lead in terms of grammaticalization in that neither of its two paradigms any longer display adjectival properties. The least grammaticalized system is the Italian, while Spanish and Romanian occupy an intermediate position: Spanish combines the French system of clitic forms with the Italian system of strong forms. As for Romanian, the dependence of the possessive form on the definite article or its substitute $A L$ shows that it is more grammaticalized than the Italian.
\end{abstract}

Keywords (4-6)

Romance, possessives, adjectives, determiners, grammaticalization, clitics

\author{
Author: \\ Marleen Van Peteghem \\ Universiteit Gent \\ Vakgroep Frans - Contragram \\ Blandijnberg 2 \\ 9000 Gent (Belgium) \\ Marleen.VanPeteghem@UGent.be
}

Fax 00.32.9.264.41.74 


\section{Introduction}

This paper deals with possessives in four Romance languages: French, Italian, Spanish and Romanian. As is well known, these languages display many differences with respect to the distribution of their possessive forms, although all these forms derive etymologically from Latin. However, whereas in Latin the possessives are strong forms exhibiting a distribution similar to that of lexical adjectives ${ }^{1}$, this is not the case for most possessives in Romance languages. Although the strong forms found in the four languages display an adjectival morphology, their distribution does not match with that of lexical adjectives. Moreover, some of these languages, such as French and Spanish, have developed, in addition, a weak paradigm with determiner-like properties, which is in complementary distribution with the strong form.

The aim of my contribution is (i) to examine to what extent the possessive systems of the above mentioned four Romance languages are mutually divergent and (ii) to verify whether the observed differences can be regarded as the result of different grammaticalization paces. As all types of possessives - adjectival, pronominal or determiner-like - are basically grammatical forms, it may seem surprising to attempt to explain changes within the possessive paradigm through grammaticalization processes. After all, it is well known that grammaticalization typically involves the development of lexical forms into grammatical devices, for example lexical verbs turning into auxiliaries or inflectional affixes. However, grammaticalization may also be characterized as the development from grammatical to even more grammatical forms (see Kuryłowicz 1960) and it is this latter interpretation of the term which is adopted in this paper. As I show, all evolutions from Latin to Romance observed in the possessive system involve change of categorial status: pronouns are replaced by adjectives and adjectives change into determiners. I argue that these categorial changes are the result of grammaticalization and that this grammaticalization process is the most advanced in French, where neither of the two paradigms still displays adjectival properties. It is the least advanced in Italian, where possessives are still highly adjectival. As for Spanish, it has weak determiner forms for the prenominal possessives and strong adjectival forms for the postnominal forms, thus occupying an intermediate position between French and Italian. Finally, the Romanian system stands entirely apart since the possessive depends on the morpheme al, often called the "possessive article", which has no counterpart in the other languages.

This paper is structured as follows. Section 2 will provide a quick survey of the different types of possessives found in the four Romance languages under discussion and will show that these paradigms tend to eliminate pronominal possessives. Section 3 will examine how strong possessives have become clitic determiners in French and in Spanish. Section 4 will deal with the morphological and distributional properties of the strong forms in the four languages and will show that the French mien is the most deficient, having lost most of its adjectival properties.

\section{From pronouns to adjectives}

Table 1 provides a survey of the masculine possessive forms found in Latin and in the four Romance languages considered here.

\footnotetext{
${ }^{1}$ In Latin the possessive can appear in the same positions as lexical adjectives, i.e. both as a nominal modifier and as a predicate. However, it cannot be coordinated with a lexical adjective.
} 


\begin{tabular}{|c|c|c|c|c|c|c|c|c|}
\hline & & Latin & \multicolumn{2}{|c|}{ French } & \multicolumn{2}{|c|}{ Spanish } & \multirow[t]{2}{*}{ Italian } & \multirow{2}{*}{ Romanian } \\
\hline & & & clitic & strong & clitic & strong & & \\
\hline \multirow[t]{3}{*}{ SG } & 1 & meus & mon & mien & $\mathrm{mi}$ & mio & mio & meu \\
\hline & 2 & tuus & ton & tien & tu & tuyo & tuo & tău \\
\hline & 3 & eius $^{2} /$ suus & son & sien & $\mathrm{su}$ & suyo & suo & lui / său \\
\hline \multirow[t]{3}{*}{ PL } & 1 & noster & notre & nôtre & \multicolumn{2}{|c|}{ nuestro } & nostro & nostru \\
\hline & 2 & voster & votre & vôtre & \multicolumn{2}{|c|}{ vuestro } & vostro & vostru \\
\hline & 3 & eorum / sui & \multicolumn{2}{|c|}{ leur } & $\mathrm{su}$ & suyo & loro & lor \\
\hline
\end{tabular}

Table 1. Possessives in Latin and Romance

\subsection{Three types of possessives}

As shown in various studies (cf. Cardinaletti 1998, Schoorlemmer 1998, Zribi-Hertz 1999, Ihsane 2000, Alexiadou 2004), these paradigms are heterogeneous in that they contain different types of possessives. Although these studies differ in their analyses of particular forms, they all agree in distinguishing the following three types of possessives, illustrated here by the most representative example found in the four languages:

- The adjectival type, such as the Italian possessive mio $\left(1 \mathrm{MSG}^{3}\right)$, which exhibits an adjectival distribution in that it can occur as an attribute, either in prenominal or postnominal position, and as a predicate.

$$
\begin{aligned}
& \text { It. a. un mio libro } \\
& \text { a mine book } \\
& \text { 'my book' }
\end{aligned}
$$
b. un libro mio book mine 'a book of mine' c. questo libro è mio this book is mine 'this book is mine'

- The determiner type, such as French mon and Spanish mi, whose distribution is determinerlike in that it can license an NP and does not combine with other determiners.

$$
\begin{array}{ll}
\text { Fr. a. mon livre } \\
\text { Sp. } & \text { b. mi libro } \\
& \text { my book } \\
& \text { 'my book' }
\end{array}
$$

b. *le / ce / un mon livre

b. *ell este/un mi libro the/ this / a my book

- The pronominal type, exemplified by the Romanian forms 3MSG lui-3FSG ei-3PL lor, which are formally identical to the corresponding genitive/dative strong forms of the personal pronoun.

$$
\text { Rom. a. carte- a lui }
$$

b. carte-a ei

c. carte-a lor

\footnotetext{
${ }^{2}$ Eius (PL eorum/earum) is in fact the genitive form of the demonstrative pronoun is, which is unmarked as to distance (cf. infra 2.3.). It has various pronominal uses. When it appears in the genitive in an adnominal position, it expresses a relation of possession. It has to be noted that in Latin the genitive of other pronouns, such as demonstratives (hic, iste, ille) or identity markers (cf. ipse, idem), can also be used as a possessive form.

${ }^{3}$ We will use the following abbreviations: Fr. $=$ French; It. $=$ Italian; Rom. $=$ Romanian; Sp. $=$ Spanish; $1=$ first person; 2 second person; $3=$ third person; $\mathrm{SG}=$ singular; $\mathrm{PL}=$ plural; $\mathrm{MSG}=$ masculine singular; $\mathrm{MPL}=$ masculine plural; FSG = feminine singular; FPL $=$ feminine plural; $\mathrm{NSG}=$ neuter singular; DAT $=$ dative; GEN $=$ genitive; $\mathrm{CL}=$ clitic; $\mathrm{POL}=$ politeness form; $\mathrm{AL} / \mathrm{A} / \mathrm{AI} / \mathrm{ALE}=$ forms of the possessive article in Romanian.
} 


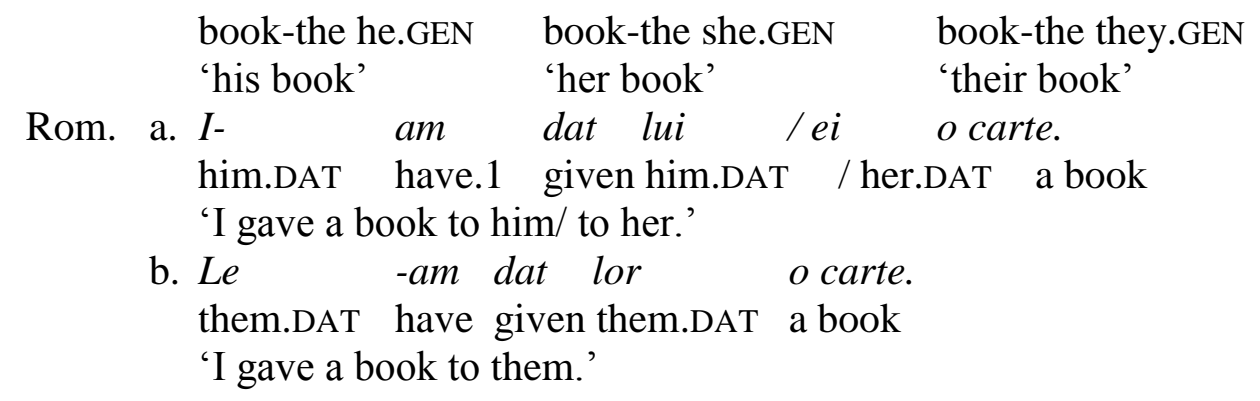

\subsection{Two agreement patterns}

The heterogeneity of the possessive paradigm in one and the same language and its crosslinguistic variability can be explained by the double status of possessives. Syntactically they appear in an adnominal position, and tend therefore to behave either as an adjunct or as a specifier. However, from a semantic and referential point of view they behave like pronouns, in that they refer to an entity, which I will call the possessor. As also is the case with personal pronouns, this possessor can be identified either deictically or anaphorically. Furthermore, the $3^{\text {th }}$ person pronouns constitute the pronominal counterparts of lexical possessive $\mathrm{PPs}^{4}$ (cf. (6)) or genitive NPs in case languages. As shown in (7), possessives can be coordinated with lexical PPs in Italian and Spanish or with lexical genitives in Romanian.

Fr.
a. le livre de Jean
the book of John

'John's book'

b. son livre

his book

'his book'
a. It. la sofferenza tua e di tanti altri
the sufferance yours and of so.many others
'your sufferance and the sufferance of so many others'
b. Sp. la salud tuya y de tu pareja
the health yours and of your couple
'your health and the health of your couple'
(Internet)
c. Rom. activitate- $a$ ta şi a echipe- $i$ tale (Internet)
activity-the yours and A team.GEN-the.GEN yours.GEN
'your activity and the activity of your team'
(Internet)

Moreover, $3^{\text {th }}$ person possessives display a pronominal-like behavior with respect to binding: like pronouns, they can be bound by a c-commanding quantifier (cf. (8)a) and are able to bind a reflexive (cf. (8)b) (cf. Antrim 2003: 8).

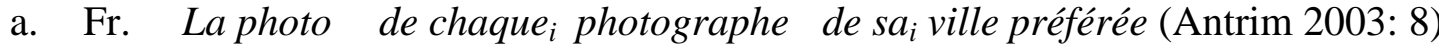
the picture of each photographer of his town favorite
'The picture of each photographer of his favorite town'
b. Sp. Su foto de él $i_{i}$ mismo (Antrim 2003: 8) his picture of him self

\footnotetext{
${ }^{4}$ For a study of the relationship between the possessive modifier and its lexical counterpart, see amongst others Milner (1982), Godard (1986), Gross (1986), Bartning (1989).
} 
This double status of possessives, which are syntactically modifiers or specifiers and referentially pronouns, explains why they can be categorized either as adjectives/determiners or as pronouns. For possessives, the most salient difference between these categories is their agreement pattern: pronominal possessives inherit their features (person, gender, number) from their referent or antecedent, while adjectival or specifying possessives agree in gender and number with the head noun. However, all possessive forms exhibit person and number agreement with the possessor. As a consequence, the adjectival and determiner forms show a hybrid agreement pattern: with the possessor with respect to person and number; with the head noun with respect to number and gender.

This double agreement pattern does not raise problems since the two patterns are expressed differently. The agreement with the possessor is expressed by the root of the possessive forms, hence lexically, and is therefore not grammatical agreement but referential concord. The agreement with the head noun is marked by inflectional morphemes and is triggered by grammatical relations only, as clearly appears from the glosses of the following Italian examples.

$$
\begin{aligned}
& \text { it. a. il mi-o libro } \\
& \text { the 1SG-MSG book } \\
& \text { 'my book' }
\end{aligned}
$$
b. la tu-a casa the 2SG-FSG house 'my house'
c. $i$ suo- $i$ problemi the 3SG-PL problems 'my problems'

Although all possessives are pronouns and are labelled so in most grammatical traditions, I will henceforth restrict the use of the term pronoun to the non agreeing forms.

\subsection{Possessive pronouns in Romance}

The existence of several types of possessives can already be observed in the Latin system, which contained two of them, the agreeing type (1MSG meus - 1FSG mea - 1NSG meum) and the non agreeing one (3SG eius - 3MPL eorum - 3FPL earum), corresponding to the genitive case of the personal pronoun 3MSG is. It is important to note that, in both Latin and Romance, the non agreeing forms occur only in the $3^{\text {th }}$ person, singular and plural, and not in the deictic $1^{\text {st }}-2^{\text {nd }}$ persons. Furthermore, in Classical Latin the genitive pronoun occurred only in contexts of discourse anaphora, but not in those of bound anaphora, where the use of reflexive suus was compulsory. We can thus infer that the use of the possessive pronoun was restricted to contexts giving rise to ambiguity in the identification of the antecedent and, hence, aimed at reducing this ambiguity through agreement of the pronoun with its antecedent. However, for referentially non ambiguous possessives, such as deictics or reflexive possessives, Latin had exclusively agreeing forms (1MSG meus - 2MSG tuus - 3MSG suus).

A glance at table (1) shows that most possessive pronouns were lost in the evolution from Latin to the Romance languages. Especially for the singular forms, three of the four languages have replaced the 3SG pronoun with the reflexive form, which has thus lost its reflexive use. As noted by Stotz (1998: 292-293), this loss of reflexivity can also be observed in Medieval Latin. In the 3SG person, only Romanian still has genuine pronouns. However, 3MSG lui and 3FSG ei derive etymologically from the dative pronouns illui $(<i l l e)$ and $e i(<i s)$. In contemporary Romanian, these forms occur either as adnominal genitive or strong dative pronouns, as the Romanian case system shows syncretism between the genitive and the dative. 
b. I- am dat lui/ei o carte. him/her.CL.DAT have given him/her.DAT a book 'I have given a book to him / to her.'

Notice, though, that, in literary Romanian, dative clitics (3SG but mostly 1-2sG clitics) can also be used as adnominal possessives. Therefore, the question arises as to whether the strong adnominal pronouns lui/ei are to be analyzed as genitive marked, or rather, as argued by Ortman \& Popescu (2000), as dative marked. As this issue goes beyond the scope of this paper, I will not discuss it here.

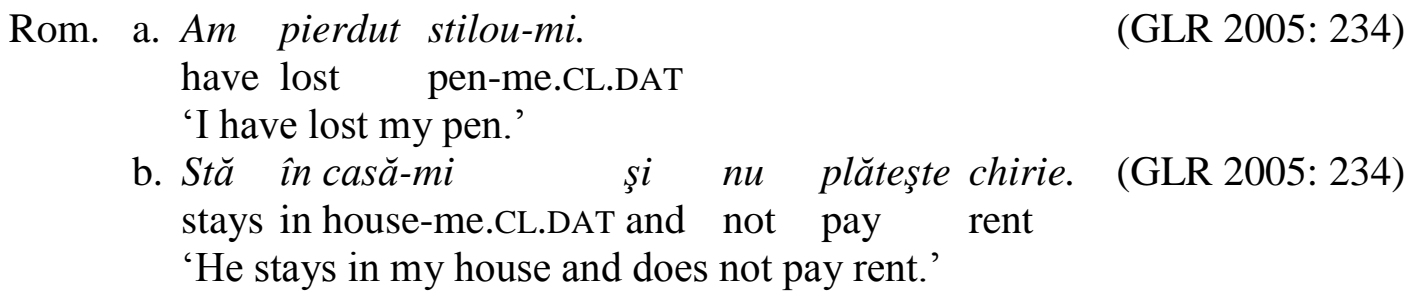

A further point of note is that the genitive possessive pronouns alternate with the agreeing form său, derived from the reflexive suus. As in Medieval Latin and in the other Romance languages, $s \breve{a} u$ has lost its reflexive use. It is generally used in written and rather formal language, the genitive pronoun being the most usual form in spoken language ${ }^{5}$. The survival of the genitive pronouns as possessives in Romanian can be explained by two factors. The first is that Romanian is still a case language and that, morphologically, the genitive pronouns display roughly the same inflection as other genitive-marked words.

$$
\begin{aligned}
& \text { Rom. a. carte-a l-ui /e-i /l-or } \\
& \text { book-the him-GEN / her-GEN / them-GEN } \\
& \text { 'his / her / their book' } \\
& \text { b. carte-a băiat-ul-ui /fete-i /băieți-l-or } \\
& \text { book-the boy-the-GEN / girl-the.GEN / boys-the-GEN } \\
& \text { 'The boy's / girl's / boys' book' }
\end{aligned}
$$

The second factor is that, in Romanian, definite determiners and determiner-like adjectives such as demonstratives and possessives are generally postposed to the head noun. The postposition of the genitive pronoun to the head noun yields a strong parallel with genitive NPs, with which the possessives can be coordinated, as already shown in example (7). However, the distribution of the genitive pronouns is somewhat different from that of genitive NPs. For instance, unlike the latter, genitive pronouns (as well as possessive adjectives) can occur before the noun when they follow an adjective bearing the enclitic definite article (or are preceded by the morpheme $a$, which will be commented below).

$$
\begin{aligned}
& \text { Rom. a. mare- } a \text { ei iubire vs } \\
& \text { great-the hers love } \\
& \text { 'her great love' }
\end{aligned}
$$

\section{b. *mare-a Marie- $i$ iubire great-the Mary-GEN love}

\footnotetext{
${ }^{5}$ For a study of the competition between the possessive pronoun and the possessive adjective său, see Niculescu (2004).
} 
As for the 3PL possessive form, the evolution of the possessives has been more diverse. As can be seen from table (1), the Latin GEN PL personal pronouns eorum/earum have not survived in Romance. Spanish has chosen the reflexive suus, which thus neutralizes not only the gender of the possessor, but also its number. The three other languages have replaced these personal pronouns with the GEN MPL demonstrative illorum, which tended to replace both the masculine eorum and the feminine earum in Late Latin (see Stotz 1998: 293). In all three languages, the forms derived from illorum are also used as dative pronouns; that is, as a dative clitic pronoun in French, as a strong dative pronoun in Romanian and as a strong or weak form in Italian.
a. Fr. Je leur ai donné un livre.
I them.DAT have given a book.
'I gave them a book.'
b. Rom.Le- am dat lor carte-a. them.DAT have given them.DAT book-the 'I gave the book to them.'
c. It. Ho dato (?a) loro un libro. have given them.DAT a book 'I gave them a book.'

However, from a morphological point of view, only Romanian lor and Italian loro still behave like genuine pronouns in that they do not agree with the head noun. French leur, on the other hand, exhibits number agreement which is audible in liaison contexts. We can thus conclude that this pronoun has been adjectivized in French.
a. Rom. carte- $a$ lor book-the them.DAT
b. It.
il loro libro
the.SG their book
'Their book'
a'. cărțile lor books-the them.DAT
b'. $i \quad$ loro libri
the.PL their books
'Their books'
c. Fr. leur enfant
their.SG child
c'.leurs enfants
their.PL children

Notice that, whereas in Romanian lor is part of a paradigm of $3^{\text {th }}$ person possessive pronouns, in modern Italian loro is an idiosyncratic pronoun within the possessive paradigm. However, in Old Italian, loro constituted a paradigm with the possessive pronouns 3MSG lui - 3FSG lei, which have lost the oblique cases in contemporary Italian (see Rohlfs 1970, Stefanini 1976, Cardinaletti 1998). As shown in (16)c this possessive use of the pronoun lui is attested in Italian until the $19^{\text {th }}$ century, but was in competition with the much more frequent prepositional use il di lui $\mathrm{N}$, a structure which is still used in modern Italian (cf. (16)d, see also Salvi \& Renzi 2010: 368).
Old It. a. il lui
padre
b. il
lei marito
the him.GEN/DAT father 'his father'
the her.GEN/DAT husband 'her husband'
c. il lui
padre
era morto due anni innanzi. (Vittorio Alfieri, 1809)
the him.GEN/DAT father
was dead
two years before
'His father died two years before.' 
Mod. It. d. costringendo-lo però ad adottare il di lui nipote Germanico, (MON2001_04) forcing-him however to adopt the of him nephew Germanico 'but forcing him to adopt his nephew Germanico'

This shows that the pronoun loro is a remnant of a system of $3^{\text {rd }}$ person possessive pronouns, similar to the Romanian system ${ }^{6}$.

We can thus summarize as follows: in the evolution from Latin to Romance languages, possessive pronouns tended to be replaced with agreeing forms, the only surviving pronouns being It. 3PL loro and Rom. 3SG+PL lui/ei/lor. The question is whether this evolution can be described as a case of grammaticalization. At first glance, the answer to this question might seem to be negative, as pronouns are more grammatical than the basically lexical category of adjectives. However, given that the pronominal forms correspond more directly to their lexical counterparts, which are DPs, the replacement of pronouns with agreeing forms can be explained by the predominance of the syntactic position of the possessive within the NP over its referential function. From this respective, Spanish has the most advanced system, immediately followed by French, where the pronoun leur has turned into an agreeing form. Romanian is clearly the less evolved language in that it has a complete system of genuine pronouns for 3SG and 3PL, while Italian loro is an idiosyncratic possessive pronoun within an agreeing possessive paradigm.

\footnotetext{
${ }^{6}$ Cardinaletti (1998) analyzes loro as a DP-internal weak pronoun, which contrasts with both the prenominal and the postnominal possessive adjectives, which are strong forms. However, the data on which this claim is based are controversial. According to Cardinaletti (1998), loro cannot appear in predicative position, nor in isolation nor in certain elliptic NPs, and cannot be used without the article with kinship nouns (cf. infra, example (25)).

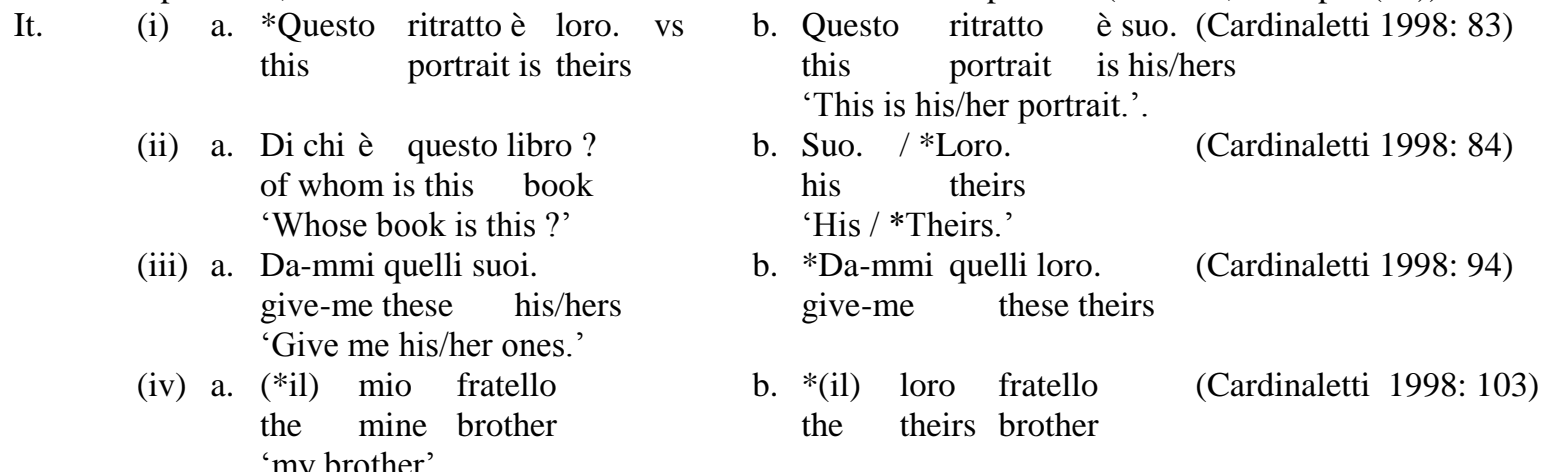

Nevertheless the contrast between loro and possessive adjectives is not as clear-cut as claimed by Cardinaletti. Examples such as (ia) are attested (cf. (v)), and 0 and (iiib), although considered both ungrammatical by some speakers of Italian, are attested, which shows that the use of loro differs less from that of the other possessives than argued by Cardinaletti. For further critical remarks on the claim of Cardinaletti, see Ihsane (2000).

It. (v) i suoi libri, quelli di altri e quelli suoi, (Stampaquot-Corpus Coris)

the his/hers books, those of others and those his/hers 'his/hers books, those of the others and his/hers"

(vi) tra gli interessi nostri e quelli loro (www.brugnatelli.net/.../040106-CostituzioneEuro... ) between the interests ours and those theirs 'between our interests and theirs' 


\section{From strong adjectival forms to clitic determiners}

As noted above, French and Spanish have two complete paradigms of possessives: a weak form (Fr. mon, Sp. mi) and a strong form (Fr. mien, Sp. mío). Both forms derive from the Latin accusative meum and display an adjectival agreement pattern in that they agree in number and gender with the head noun. However, these two paradigms do not alternate in the same syntactic positions. As shown by Cardinaletti (1998), Schoorlemmer (1998), Zribi-Hertz (1999), Ihsane (2000), Antrim (2003) and Alexiadou (2004), the weak type behaves syntactically like a determiner, while the behaviour of the strong form, albeit with many restrictions on context (see section 4 below), is closer to that of lexical adjectives. In this section, I will concentrate on the weak form and investigate the extent to which its distribution is similar to that of other determiners, such as articles.

\subsection{Possessives as determiners}

The possessive determiners of French and Spanish share three crucial properties with articles:

1) Contrary to their strong counterparts in all four languages, ${ }^{7}$ they can license an NP.
a. Fr. Mon livre est sur la table
vs a'. *Mien livre est sur la table. mine book is on the table my book is on the table
b. Sp. Mi libro está en la mesa. b'. *Libro mío está en la mesa. my book is in the table book mine is in the table 'My book is on the table.'
c. It. *Mio libro è su-lla tavola. mine book is on the table
d. Rom. *Carte mea e pe masă. book mine is on table

\footnotetext{
${ }^{7}$ In Italian and in Spanish, the strong forms can also appear without the article, thus giving rise to apparent counterexamples. However, the possessive NP appears in contexts allowing the absence of the article, such as predicates (ia), vocatives or exclamations (ib), indefinite plurals (ic, iia) and negative contexts (iib). Moreover, in some of these examples the strong possessive is postposed to the head noun, a position which is not accessible to determiners.

(i) It. a. Saró sempre tua amica. (Cordin 1988: 607) will.bealways your friend 'I will always be your friend.'

b. Caro mio! Dio mio! (Cordin 1988: 610) dear mine god mine 'My dear!' 'My god!'

c. Arrivavano vostri amici a tutte le ore. arrived your friends at all the hours 'Your friends came at any hour.'

(ii) Sp. a. Hay acuarelas tuyas por toda la casa. (Picallo \& Rigau 1999: 992) there.are watercolours yours through whole the house 'There are watercolours of yours throughout the house."

b. No es culpa mía. not is fault mine 'It is not my fault.'
} 
2) They cannot combine with other determiner-like words such as articles, demonstratives or certain indefinites, with which they are in complementary distribution ${ }^{8}$, while the strong ones do enter into such combinations, although - as we will see in section 4 - the conditions under which these combinations are possible differ from one language to another.
a. Fr. *Pierre aime la / cette ta robe.
Peter likes the / this your dress.
b. Sp. *Un mi hermano / *algún mi libro (Picallo \& Rigau 1999: 977)
a my brother / some my book

3) They always require the presence of a lexical head' (cf. Zribi-Hertz 1999).
a. Fr. *Pierre aime ta robe, mais il n' aime pas ma/la ma.
Peter likes your dress but he not likes not my/the my
b. Sp. *APedro le gusta tu vestido, perono le gusta mi/el mi. to Peter him.DAT pleases your dress but not him.DAT pleases my / the my

\subsection{Possessives as clitics}

These latter two properties have led various linguists to regard possessive determiners as clitics (see Cardinaletti 1998, Schoorlemmer 1998, Zribi-Hertz 1999, Ihsane 2000, Antrim 2003, Alexiadou 2004, among many others). Some of the additional arguments they present in favour of this claim are the following:

- $\quad$ Like clitics, they cannot be coordinated (unlike the strong forms - see example (41) below).
a. Fr. *ma et ta photo
cf. a'. *la et cette photo
b. Sp. *mi y tu foto
my and your photograph
a'. *la y esta foto
the and this photograph

- $\quad$ They can co-occur with strong pronouns in a clitic doubling construction (cf. Cardinaletti (1998: 77) for French), a construction which, in Spanish, is very frequent with the pronoun $s u+$ usted (cf. Picallo \& Rigau 1999: 981).

$$
\begin{aligned}
& \text { a. Fr. } \begin{array}{l}
\text { son livre àlui } \\
\text { his book of his }
\end{array}
\end{aligned}
$$

\footnotetext{
${ }^{8}$ However, as noted by Picallo \& Rigau (1999: 977), in Spanish the strong possessive does co-occur with the demonstrative, but only in formal language. They also observe that in several northern dialects of Spain, such as those spoken in Leon and Asturias, the prenominal possessive can also co-occur with the definite article (la mi casa, el mi pueblo).

${ }^{9}$ Notice, though, that possessive determiners differ from articles in that they require the presence of a noun, while the definite article can license an NP with an empty noun.

(i) Fr. Pierre aime ma robe noire, mais il n'aime pas la rouge /*ma rouge.

Peter likes my dress black but he not likes not the red / my red 'Peter likes my black dress, but he does not like my red one.'
} 
'HIS book'

b. Sp. Yo conocí a su madre de usted.
I acquainted to your mother to you.POL
'I got acquainted with your mother.'

As shown by Picallo \& Rigau (1999: 981), in various Spanish dialects (Mexico, Andes), clitic doubling even occurs with lexical PPs.

$$
\begin{aligned}
& \text { Sp. Su novio de Juana. (Picallo \& Rigau 1999: 981) } \\
& \text { his fiancé of Juana } \\
& \text { 'Juana's fiancé' }
\end{aligned}
$$

- $\quad$ They can license floating quantifiers (cf. Cardinaletti 1998: 78).
a. Fr. notre mère à tous
our mother to all
b. Sp. nuestra madre de todos
our mother of all
'mother to us all'

Evidently, as argued by Alexiadou (2004) for the possessives in French, English and German, the cliticization of possessive forms is a strong argument in favour of the grammaticalization of the possessive paradigm in French and in Spanish. As shown by Hopper \& Traugott (1993: 7), cliticization is the penultimate stage in the cline of grammaticality, which they present as follows:

$$
\text { content word > grammatical word }>\text { clitic }>\text { inflectional affix }
$$

In Spanish, the grammaticalization of the prenominal weak possessive is also confirmed by phonetic and morphological erosion, another clear symptom of both grammaticalization and cliticisation (cf. Antrim 2003). Although Spanish has a rich morphology of the agglutinating type, separating gender and number morphemes (-o/- $a$ for the gender distinction and $-\phi /-s$ for the number distinction, cf. (24)), the morphology of the possessive determiner is extremely reduced, neutralizing gender oppositions in the singular and in the 3PL forms, as is demonstrated in table 2.

$$
\begin{aligned}
& \text { MSG buen-o- } \phi \quad \text { FSG buen- } a-\phi \quad \text { MPL } b u e n-o-s \quad \text { FPL } b u e n-a-s \\
& \text { good-M-SG good-F-SG good-M-PL good-F-PL }
\end{aligned}
$$

\begin{tabular}{|l|l|l|l|l|}
\hline & MSG & FSG & MPL & FPL \\
\hline 1SG & \multicolumn{2}{|c|}{ mi- $\varnothing$} & \multicolumn{2}{c|}{ mi-s } \\
\hline 2SG & \multicolumn{2}{|c|}{ tu- $\varnothing$} & \multicolumn{2}{c|}{ tu-s } \\
\hline 3SG & \multicolumn{2}{|c|}{ su- $\varnothing$} & \multicolumn{2}{c|}{ su-s } \\
\hline 1PL & nuestr-o & nuestr-a & nuestr-os & nuestr-os \\
\hline 2PL & vuestr-o & vuestr-a & vuestr-os & vuestr-as \\
\hline 3PL & \multicolumn{2}{|c|}{ su- $\varnothing$} & \multicolumn{2}{c|}{ sus } \\
\hline
\end{tabular}

Table 2. Clitic determiner possessives in Spanish 
While the morphology of the weak paradigm in French is richer than that of Spanish in that it shows gender distinctions in the singular, it displays two particularities which argue in favour of its grammaticalization:

- the feminine singular is marked by the morpheme $-a$, just as for the definite article, while lexical adjectives take the feminine morpheme $-e$ (cf. MSG grand - FSG grande 'big');

- the 1PL and 2PL forms exhibit an irregular morphology, which is not found anywhere else in French morphology.

\begin{tabular}{|l|c|c|c|}
\hline & MSG & FSG & MPL/FPL \\
\hline article & le & $l-a$ & l-es \\
\hline 1SG & mon & m-a & m-es \\
\hline 2SG & ton & t-a & t-es \\
\hline 3SG & son & s-a & s-es \\
\hline adjective & \multicolumn{2}{|c|}{ bête } & bête-s \\
\hline 1PL & \multicolumn{2}{|c|}{ notre } & nos \\
\hline 2PL & \multicolumn{2}{|c|}{ votre } & vos \\
\hline 3PL & \multicolumn{2}{|c|}{ leur } & leur-s \\
\hline
\end{tabular}

Table 3. Clitic determiner possessives in French

Some initial stages of cliticization and grammaticalization can also be found in Italian and in Romanian, where prenominal possessives can occur without the article when used with certain kinship nouns. In Italian, this article-less construction is compulsory with singular non-derived kinship nouns, but agrammatical with plural and derived kinship nouns. In Romanian it is restricted to a few singular kinship nouns in informal spoken language.

It. a. (*il) tuo fratello ̀̀ molto stanco the yours brother is very tired 'Your brother is very tired.'

vs
b. *(i) miei fratelli sono molto stanchi the mine brothers are very tired 'My brothers are very tired.' the yours brother-DIM is very tired 'your little brother is very tired.'
c. *(il) tuo fratell-ino è molto stanco
Rom. a. maică-mea
b. frate-meu
c. soră-mea
mum mine
brother mine
sister mine
d. unchiu-meu
'my mum'
'my brother'
'my sister'
uncle mine
'my uncle'

According to Cardinaletti (1998), the Italian possessive displays clitic behaviour in these uses, whereas in its prenominal position it behaves as a weak form and in postnominal uses as a strong form, although all these forms are homophonous. She justifies this claim by noting that, used with kinship nouns, they cannot occur alone, either in ellipsis (27)a) or in isolation (27)b), nor can they be contrasted (27)c) or coordinated (27)e).

$$
\begin{aligned}
& \text { It. a. Mio fratello verrà, *(il) suo invece no. } \\
& \text { mine brother will.come, the yours on.the.other.hand not } \\
& \text { 'My brother will come, while yours will not.' }
\end{aligned}
$$



b. Verrà tuo fratello o il fratello di Gianni? *(Il) suo. will.come your brother or the brother of Gianni ? (the) his.
'Who will come, your brother or John's ? His.
c. *mio padre, non suo
mine father, not his
d. *mio e suo padre
my and his father

This claim is supported by the fact that, in similar uses in Romanian, certain possessive forms such as său tend to appear in a short clitic form in a very informal register, which confirms that this article-less use is a first step towards cliticisation.
Rom. a. frate-su
brother his
b. tat-su / tac-su / ta-su
'his brother'
father his
'his father'

Conversely, it should be noted that in old French the clitic pronoun is compatible with articles, as is shown by the following example, taken from Buridant (2000: 155). This construction has since been lost.

$$
\begin{aligned}
& \text { Fr. Par un son fils a il trop grand dehait (Poème-Buridant 155) } \\
& \text { by a his son has he too big pain } \\
& \text { 'Because of one of his sons, he has too much pain.' }
\end{aligned}
$$

This diachronic development may suggest that the evolution of possessives passes through two steps: first, strong forms become weak prenominal ones, used with another determiner; subsequently, the weak prenominal forms tend to occupy the determiner position and undergo cliticization.

The observations made in this section confirm the conclusion reached in the preceding section. They show that both Spanish and French have the most grammaticalized possessive paradigm: both languages have completely eliminated the possessive pronouns and both have developed clitic determiners. By contrast, the Italian and Romanian paradigms still contain pronouns and exhibit few instances of cliticisation (see also Van Peteghem 2011).

\section{From genuine adjectives to deficient adjectives}

\subsection{The declension of strong possessives}

Let us now concentrate on the analysis of the strong forms. All four languages have strong possessives, exhibiting the same number and gender morphemes as lexical adjectives. Interestingly, the most complete paradigms can be found in Spanish, immediately followed by Italian, which displays the same oppositions as Spanish, with the exception of the 3PL invariable pronoun loro, as discussed in section 2. As for French, the strong possessive has a reduced morphology: in the plural forms, the gender opposition is completely neutralized, and in the whole paradigm the number oppositions are marked only in the written forms. In the oral language they are marked by the definite article, with which the possessive is obligatorily used. It has to be noted that the declension of the plural forms, neutralizing gender and in oral speech also 
number, is consistent with the declension type found with lexical adjectives ending in $-e$, such as rustre.

\begin{tabular}{|l|c|c|c|c|}
\hline & MSG & FSG & MPL & FPL \\
\hline adj & buen-o & buen- $a$ & buen-os & buen-as \\
\hline 1SG & mí-o & mí-a & mí-os & mí-as \\
\hline 2SG & tuy-o & tuy-a & tuy-os & tuy-as \\
\hline 3SG & suy-o & suy-a & suy-os & suy-as \\
\hline 1SG & nuestr-o & nuestr-a & nuestr-os & nuestr-as \\
\hline 2SG & vuestr-o & vuestr-a & vuestr-os & vuestr-as \\
\hline 3SG & suy-o & suy-a & suy-os & suy-as \\
\hline
\end{tabular}

Table 4. Strong possessives in Spanish

\begin{tabular}{|l|c|c|c|c|}
\hline & MSG & FSG & MPL & FPL \\
\hline adj & buon-o & buon-a & buon-i & buon-e \\
\hline 1SG & mi-o & mi-a & mie-i & mi-e \\
\hline 2SG & tu-o & tu-a & tuo-i & tu-e \\
\hline 3SG & su-o & su-a & suo-i & su-e \\
\hline 1PL & nostr-o & nostr-a & nostr-i & nostr-e \\
\hline 2PL & vostr-o & vostr-a & vostr-i & vostr-e \\
\hline 3PL & \multicolumn{5}{|c|}{ loro } \\
\hline
\end{tabular}

Table 5. Strong possessives in Italian

\begin{tabular}{|l|c|l|c|c|}
\hline & MSG & FSG & MPL & FPL \\
\hline adj & aérien- $\varnothing$ & arien-ne & aérien-s & aérien-nes \\
\hline 1SG & mien- $\varnothing$ & mien-ne & mien-s & mien-nes \\
\hline 2SG & tien- $\varnothing$ & tien-ne & tien-s & tien-nes \\
\hline 3SG & sien- $\varnothing$ & sien-ne & sien-s & sien-nes \\
\hline adj & \multicolumn{2}{|c|}{ rustre } & \multicolumn{2}{|c|}{ rustre-s } \\
\hline 1SG & \multicolumn{2}{|c|}{ nôtre } & \multicolumn{2}{c|}{ nôtre-s } \\
\hline 2SG & \multicolumn{2}{|c|}{ vôtre } & \multicolumn{2}{|c|}{ vôtre-s } \\
\hline 3PL & \multicolumn{2}{|c|}{ leur } & \multicolumn{2}{c|}{ leur-s } \\
\hline
\end{tabular}

Table 6. Strong possessives in French

The most peculiar declension is found in Romanian. Although gender and number agreement with the head noun are systematically marked (except for the pronouns lui/ei/lor, as noted above), the typical adjectival morphology is found only with the 1PL and 2PL forms. The other forms display a determiner-like morphology in the feminine, the morphemes being FSG $-a$, FPL $-l e$, which contrast with the adjectival endings $-\breve{a} /-e$. The $-a$-le opposition is mainly found with determiners such as the enclitic definite article, the demonstratives cel and acel and the so-called "possessive article" al, which will be discussed below. However, it appears also with a few lexical adjectives such as greu ('heavy', 'difficult', cf. greu, grea, grei, grele). We can thus say that, morphologically, the strong possessive corresponds more to determiners than to adjectives in Romanian, and is therefore the least adjectival one. 


\begin{tabular}{|l|c|l|l|l|}
\hline & MSG & FSG & MPL & FPL \\
\hline Adjective & prost & proast- $\breve{a}$ & proşt- $i$ & proast-e \\
\hline 1PL & nostr-u & noastr-ă & noştr-i & noastr-e \\
\hline 2PL & vostr-u & voastr-ă & voştr-i & voastr-e \\
\hline
\end{tabular}

Table 7. 1PL and 2PL strong possessives in Romanian

\begin{tabular}{|l|c|c|c|c|}
\hline & MSG & FSG & MPL & FPL \\
\hline article & $-u l$ & $-a$ & $-i$ & $-l e$ \\
\hline 1SG & me-u & me-a & me-i & me-le \\
\hline 2SG & tă-u & t-a & tă-i & ta-le \\
\hline 3SG & să-u & s-a & să-i & sa-le \\
\hline
\end{tabular}

Table 8. SG strong possessives in Romanian

\subsection{The distribution of strong possessives}

A distributional analysis of the strong possessives in the four languages, however, leads to a completely different result, especially for French. The following data show that French mien no longer behaves as an adjective and is highly deficient from a distributional point of view. The same goes for Romanian, in contrast to Spanish and Italian, where the distribution of strong possessives is very similar to that of lexical adjectives. In what follows, I will argue in favour of the following deficiency scale for the strong possessives in the four languages under discussion:

\section{Fr. mien > Rom. meu> Sp. mío > It. mio}

This scale is motivated by the following observations:

1) In Italian, the strong possessive can occur either post-nominally or pre-nominally, just like lexical adjectives (the postnominal use being limited to focalizing contexts), whereas in Spanish it is restricted to the postnominal position.
a. It. un libro mio
a'. un mio libro
b. Sp. un libro mío
b'. *un mío libro
a book mine
a mine book
'a book of mine'

In Romanian, where both lexical adjectives and definite determiner elements, such as definite articles and demonstratives, appear post-nominally, it is generally postposed to the noun bearing the so-called "enclitic article" $-(u) l,-a,-i,-l e^{10}$ (cf. (31)). However, in a literary register it can also precede the noun, in which case it requires the presence of the "possessive" or "genitive article" al (cf. (33b)). This morpheme, which agrees in gender and number with the noun denoting the possessed item (MSG $a l$, FSG $a$, MPL $a i$, FPL $a l e^{11}$ ), appears whenever the possessive

\footnotetext{
${ }^{10}$ In the grammatical tradition of Romanian, this article is generally described as an enclitic element. However, as shown by Ortman \& Popescu (2000), it rather behaves as an affix. As this issue is not crucial here, we will not further discuss it.

${ }^{11}$ Notice that this article is composed of $a$ (deriving from the Latin preposition $\left.a d\right)$ + the enclitic definite article $(-l$, $a,-i,-l e)$. When the element to the right of the article is invariable, it appears in its basic form $a$. autor-ul a unsprezece opere
} 
modifier is not immediately adjacent to the enclitic definite article. As further analysis of this morpheme is beyond the scope of this paper, I will consider it here as a kind of substitute for the definite article. ${ }^{12}$

$$
\begin{array}{ll}
\text { Rom. a. carte- } a & \text { mea } \\
\text { book-the mine } \\
\text { 'my book' }
\end{array}
$$

$$
\begin{aligned}
& \text { b. } a \text { mea carte } \\
& \text { the mine book }
\end{aligned}
$$

By contrast, in French the strong possessive mien cannot be used as an attribute, either prenominally or post-nominally, though it could occur in pre-nominal position in Old French, as noted by Buridant (2000: 153-155).

$$
\text { Fr. *un livre mien } \quad \text { *un mien live }
$$

Old Fr.La meie mort me rent si anuissus (Roland, 2198 - Buridant 2000: 153).

the mine death me makes so anguished

'My own death fills me with such anxiety.'

2) Another important difference between the four languages bears upon the predicative use of the possessive, which is possible with or without the article in Italian and Spanish, but generally requires the presence of the definite article in French and of the article $a l$ in Romanian.
a. It. Questo libro è mio / il mio.
b. Sp. Este libro es mío / el mío.

c. Fr. Ce livre est *mien / le mien.
this book is mine the mine

vs

d. Rom. Carte-a aceasta $e$ *mea / a mea. book-the this is mine / AL mine

'This book is mine.'

\section{author-the.M A eleven opera's}

'the author of eleven opera's'

${ }^{12}$ The analysis of this al-form, which has no counterpart in other Romance languages, is controversial since it has both determiner-like and prepositional properties. It not only heads the possessive modifier, but also lexical genitive NPs whenever they are not immediately adjacent to the enclitic definite article; that is, (i) in indefinite or demonstrative NPs, in elliptic NPs, in definite NPs with an intervening postponed adjective, and also (ii) in anaphoric elliptic NPs.

(i) $O$ carte a mea

$$
\text { a book A mine }
$$

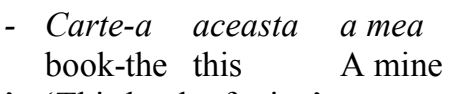

'A book of mine' 'This book of mine' 'My latest book'

Carte-a cea mai recentă a mea

(ii)

Prieten-ul meu locuieşte la Bucureşti. Al tău locuieşte la Braşov.

friend-the mine lives at Bucharest AL yours lives at Brasov

'My friend lives in Bucharest. Yours lives in Brasov.'

In (i) it behaves as an agreeing preposition-like element and has therefore been considered a "prepositional determiner" (cf. Stefănescu 1997), while in (ii) it is more determiner-like. In various studies within the framework of Generative Grammar, it is analyzed as a case assigner (see Groşu (1988), Dobrovie-Sorin (1987), Cornilescu (1995), d'Hulst, Coene \& Tasmowski (1997, 2000), Ortman \& Popescu (2000)). 
Again it has to be noted that the predicative use of mien was frequent in Old French (see Buridant (2000: 154-155) and is still possible in contemporary French, but only in a literary register and mostly in secondary predication constructions (cf. faire mien 'make mine').

Fr. a. L'on dist donc par le droit humain: ceste ville est moie, cist sers est miens, one says thus by the right human: this city is mine, this slave is mine ceste meson est moie. (Gratien - Buridant 2000: 154)

this house is mine.

'They say then, in accordance with human rights: this city is mine, this slave is mine, this house is mine.'

b. $\quad C^{\prime}$ est une des rarescertitudes maternelles quej'aie faites miennes. this is one of.the rare certainties maternal that I have made mine 'This is one of the few certainties that I have acquired as a mother.'

(Brisac 1996 - Frantext)

c. Cela suffit pour que je reconnaisse cesactions comme miennes [...]. this suffices for that I recognize these actions as mine 'That is enough to let me recognize these actions as mine.' (Ricoeur 1949 - Frantext)

3) Another distributional criterion is provided by the compatibility of the strong possessive with determiner-like elements, such as the definite and indefinite articles, demonstratives, indefinites and numerals. This criterion yields a different picture for each of the four languages. The Italian possessive is the most compatible one in that it can combine with all determiners in prenominal as well as in postnominal position. The same goes for the Spanish possessive modifier, but only in postnominal position. As for Romanian, as noted above, it requires immediate adjacency either to the enclitic definite article or to its substitute $a l$. Hence, $a l$ shows up whenever the possessive co-occurs with determiners other than the definite article.
a. It. il/ un/ questo / qualche mio libro
the / a / this / some mine book
b. Sp. el/ un/ este/algun libro mío
the / a / this / some book mine
'the / a / this / some book of mine'
c. Rom. o carte a mea/ carte-a aceasta a mea/ câteva cărti ale mele a book A mine/ book-the this A mine/ some books ALE mine 'a book of mine' / 'this book of mine' / 'some books of mine'

By contrast, the strong possessive in French, which only appears in elliptic NPs, does not combine with determiners other than the definite article. However, in Old French it was perfectly compatible within the NP with various determiners such as definite and indefinite articles and demonstratives, as shown by the examples in (37), taken from Buridant (2000: 154).

Furthermore, the Frantext corpus provides examples of co-occurrences of mine with the indefinite article up to the $17^{\text {th }}$ century and with the demonstrative up to the $18^{\text {th }}$ century. Both the attributive uses of mien and its compatibility with other determiners have been lost since the end of the $17^{\text {th }}$ century, as a result of which it has become highly deficient.

Fr. $\quad$ *ces /*quelques / *deux miens livres 

(38) Old Fr. Un leur famillier amy (Oisivetés - Buridant 2000: 154)
a their familiar friend
'A close friend of theirs'
Clas. Fr.a. Un mien ami, tant qu' il fut garçon, produisoit chaque semaine a mine friend as.long as he was boy produces each week un volume de poësies gaillardes. (Dufresny Charles - 1699 - Frantext) a volume of poems ribald 'A friend of mine, when he was young, wrote several ribald poems every week.'
b. Je vous demande excuse pour ce mien serviteur;
I you ask excuse for this mine servant
'I beg your pardon for this servant of mine.'
(Gueullette Thomas - 1756 - Frantext)

In summary, we can say that there is a clear contrast between Italian and Spanish on the one hand, where the possessive combines with all determiners under certain conditions, and contemporary French and Romanian on the other hand, where the possessive adjective is always headed by a definite article in French or by its substitute $a l$ in Romanian.

4) My final argument in favour of the deficiency scale proposed above bears upon coordination. Whereas in all four languages strong possessives can be coordinated when preceded by the article (or the al form in Romanian) (cf. (40)), in Italian and in Spanish only they can also be coordinated without the presence of the article (cf. (41)).

(41) a. It. sotto la mia e tua sorveglianza (Rodolfo Tommasi - 1997) under the mine and yours supervision 'under my supervision and yours' 'our mother'

b. Sp. la foto mía y tuya the picture mine and yours 'our picture' 13

\footnotetext{
${ }^{13}$ It has to be noted that the two constructions illustrated in (40) and (41) give rise to a different interpretation, the repetition of the article yielding a presupposition of the existence of two referents, while in the latter construction, the NP refers to one referent only.
} 
Furthermore, the Italian and Spanish postnominal possessives can be coordinated with a possessive lexical PP, and the Romanian ones with a genitive NP headed by the article, as already shown in section 2 (cf. examples (7)).

The following table summarizes the distributional properties of the six paradigms described in this paper.

\begin{tabular}{|l|c|c|c|c|c|c|}
\hline & \multicolumn{2}{|c|}{ weak possessives } & \multicolumn{4}{|c|}{ strong possessives } \\
\hline & Fr. mon & Sp. mi & Fr. mien & Sp. mí & It. mio & Rom. mea \\
\hline prenominal attribute & - & - & - & - & + & $-(\mathrm{al})$ \\
\hline postnominal attribute & - & - & - & + & + & + \\
\hline predicative position & - & - & - & + & + & $-(\mathrm{al})$ \\
\hline Co-occurrence with definite article & - & - & + & + & + & + \\
\hline Co-occurrence with other determiners & - & - & - & + & + & $-(\mathrm{al})$ \\
\hline coordination with other possessives & - & - & - & + & + & $-(\mathrm{al})$ \\
\hline
\end{tabular}

Table 9. The distribution of possessives in the four languages

From this table one can see that the weak forms do not exhibit any adjectival properties. As for the strong forms, French mien displays only one such property, its co-occurrence with the definite article (and it should be noted that this construction is possible only in elliptic NPs). Clearly, the most 'adjectival' possessive is the Italian, which displays all the adjectival properties of adjectives. The Spanish strong possessive displays all but one, the exception being that it cannot appear in prenominal position, where the use of a determiner is compulsory. Finally, the Romanian possessive is always dependent either on the enclitic definite article or on the possessive article $a l$.

\section{Conclusions and perspectives}

The above findings show that the possessive paradigm is, without any doubt, the most grammaticalized in French, for two crucial reasons: (i) it has developed a clitic determiner and (ii) its strong possessive form no longer displays an adjectival distribution. The least grammaticalized possessive paradigm is the Italian, because it is still highly adjectival. In Spanish, the possessive paradigm holds an intermediate position between these two languages in that it has a double system: a clitic determiner similar to the French, which is in an advanced stage on the grammaticalization scale, and a strong possessive, very similar to the Italian, which is less grammaticalized. As for Romanian, it exhibits a peculiar system, showing many divergences from the three other languages. These divergences are related to other grammatical differences of Romanian, such as the fact that it is a case language and that it postposes definite determiners. For this reason, it is difficult to position its possessive system on a grammaticalization scale. Nevertheless, it is clear that in this language the possessive displays fewer adjectival properties than in Italian or in the postnominal strong possessive in Spanish. However, with respect to the possessive determiner in French and Spanish and to French mien, we can only say that the possessive system has followed a totally different path in Romanian, which makes it impossible to "measure" its degree of grammaticalization.

The hypothesis presented here needs to be tested by means of a comprehensive diachronic study of the development of possessives. Such a study is essential for a full understanding of the 
evolution of possessives in Romance. It would also be interesting to flesh out this analysis with a diatopic study taking into account dialectal data. Finally, a study of the interaction of adnominal possessives with other possessive devices, such as the verbal clitic pronouns (cf. the possessive dative in all four languages, and the clitic proforms $e n$ in French and $n e$ in Italian) and possessive PPs or genitive NPs, may also shed light on the evolution of the expression of possession in the languages studied here.

\section{References}

Academia Română. 2005. Gramatica limbii româna. I. Cuvântul. Bucureşti: Editura Academiei Română.

Alexiadou, Artemis. 2004. On the development of possessive determiners: Consequences for DP structure. In Eric Fuß \& Carola Trips, eds. Diachronic clues to synchronic grammar. Amsterdam: Benjamins, 31-58.

Antrim, Nancy Mae. 2003. Number, Gender and Person Agreement in Prenominal Possessives. In William Earl Griffin, ed., The role of agreement in natural language. Texas Linguistics Forum Proceedings, 1-12.

Bartning, Inge. 1989. Le déterminant possessif et les compléments adnominaux en de. Revue Romane 24/2: 163-203.

Buridant, Claude. 2000. Grammaire nouvelle de l'ancien français. Paris: Sedes.

Cardinaletti, Anna. 1998. On the deficient/strong opposition in possessive systems. In Artemis Alexiadou \& Chris Wilder, eds. Possessors, predicates and movement in the determiner phrase. Amsterdam: Benjamins, 17-53.

Cordin, Patrizia. 1988. I possessivi: pronomi e aggettivi. In Lorenzo Renzi, ed. Grande grammatica italiana di consultazione. I. La frase. I sintagmi nominale e preposizionale. Bologna: Il Mulino, 605-616.

Cornilescu, Alexandra. 1995. Rumanian genitive constructions. In Guglielmo Cinque \& Giuliana Giusti, eds. Advances in Rumanian Linguistics. Amsterdam: Benjamins, 1-54.

D'Hulst, Yves, Martine Coene \& Liliane Tasmowski. 1997. On the syntax of Romanian possession phrases. Revue Roumaine de Linguistique 42: 149-166.

D’Hulst, Yves, Martine Coene \& Liliane Tasmowski. 2000. Last resort strategies in DP: article reduplication in Romanian and French, In Virginia Motapanyane, ed. Comparative studies in romanian syntax. Elsevier North-Holland Linguistics Series Volume 58: 135-176.

Dobrovie-Sorin, Carmen. 1987. A propos de la structure du groupe nominal en roumain. Rivista di Grammatica Generativa 12: 123-152.

Godard, Danièle. 1986. Les déterminants possessifs et les compléments de nom. Langue Française 72: 102-122.

Gross, Gaston. 1986. Syntaxe du déterminant possessif. In Jean David \& Georges Kleiber, eds. Détermination: syntaxe et sémantique. Paris: Klincksieck, 89-111.

Grosu, Alexander. 1988. On the distribution of genitive phrases in Romanian. Linguistics 26: 931-949.

Heine, Bernd \& Kuteva, Tania. 2002. World lexicon of grammaticalization. Cambridge: Cambridge University Press.

Hopper, Paul J. \& Elizabeth Closs Traugott. 2003 [1993]. Grammaticalization. Cambridge: Cambridge University Press.

Ihsane, Tabea. 2000. Three types of possessive modifiers. Generative Grammar in Geneva 1: 2154. 
Kuryłowicz, Jerzy. 1960. Esquisses linguistiques. Wrocław - Kraków: Polska Akademia Nauk. Milner, Jean-Claude. 1982. Ordres et raisons de langue. Paris: Seuil.

Niculescu, Dana. 2004. Observații privind statutul cuplului „său”/ „lui” în limba română actuală. http://ebooks.unibuc.ro/filologie/dindelegan/14.pdf

Ortmann, Albert \& Alexandra Popescu. 2000. Haplology involving morphologically bound and free elements: evidence from Romanian. Ms. Univ. Düsseldorf.

Picallo, M. Carme \& Gemma Rigau. 1999. El posesivo y las relaciones posesivas. In Ignacio Bosque \& Violeta Demonte, eds. Gramática descriptiva de la lengua española. Madrid: Espasa Calpe, 973-1023.

Rohlfs, Gerhard. 1970. Grammatica storica della lingua italiana e dei suoi dialetti. Torino: Einaudi.

Salvi, Giampaolo \& Renzi, Lorenzo. Eds. 2010. Grammatica dell'italiano antico. Bologna: Il Mulino.

Schoorlemmer, Maaike. 1998. Possessors, articles and definiteness. In Artemis Alexiadou \& Chris Wilder, eds. Possessors, predicates and movement in the determiner phrase. Amsterdam/Philadelphia: Benjamins, 55-86.

Stefanescu, Ioana. 1997. The syntax of Agreement in Romanian. Cambridge, MA: MIT Occasional Papers in Linguistics Number 14.

Stefanini, Ruggero. 1976. Nota didattica sulle forme pronominali toniche dell'italiano. Italica 53/3: 389-397

Stotz, Peter. 1998. Formenlehre, Syntax und Stilistik. München, C.H. Beck’sche Verlagsbuchhandlung.

Van Peteghem, Marleen. 2011. Possessifs et cliticisation dans les langues romanes. In Renata Enghels, Machteld Meulleman \& Clara Vanderschueren, eds. Peregrinatio in Romania. Artículos en homenaje a Eugeen Roegiest con motivo de su 65 cumpleaños. Gent: Academia Press, 249-271.

Zribi-Hertz, Anne. 1999. Le système des possessifs en français standard moderne. Langue Française 122: 7-29. 